\title{
The Responses to Long-Term Water Addition of Soil Bacterial, Archaeal, and Fungal Communities in a Desert Ecosystem
}

\author{
Ying Gao ${ }^{1, *}$, Xiaotian $\mathrm{Xu}^{1,2}{ }^{\text {, Junjun Ding }}{ }^{3}$, Fang Bao ${ }^{1}$, Yashika G. De Costa ${ }^{4}$, Weiqin Zhuang ${ }^{4}$ and Bo Wu ${ }^{1, *}$ \\ 1 Institute of Desertification Studies, Chinese Academy of Forestry, Beijing 100091, China; \\ xuxiaotian@caf.ac.cn (X.X.); baofang@caf.ac.cn (F.B.) \\ 2 Beijing Academy of Forestry and Pomology Sciences, Beijing 100093, China \\ 3 Key Laboratory of Dryland Agriculture, Ministry of Agriculture, Institute of Environment and Sustainable \\ Development in Agriculture, Chinese Academy of Agricultural Sciences, Beijing 100081, China; \\ dingjunjun@caas.cn \\ 4 Department of Civil and Environmental Engineering, The University of Auckland, Auckland 1023, \\ New Zealand; ydec845@aucklanduni.ac.nz (Y.G.D.C.); wq.zhuang@auckland.ac.nz (W.Z.) \\ * $\quad$ Correspondence: yinggao@caf.ac.cn (Y.G.); wubo@caf.ac.cn (B.W.); Tel.: +86-010-62824029 (Y.G.); \\ +86-010-62824078 (B.W.)
}

check for updates

Citation: Gao, Y.; Xu, X.; Ding, J.; Bao, F.; De Costa, Y.G.; Zhuang, W.; Wu, B. The Responses to Long-Term Water Addition of Soil Bacterial, Archaeal, and Fungal Communities in a Desert Ecosystem. Microorganisms 2021, 9, 981. https://doi.org/ 10.3390/microorganisms 9050981

Academic Editor: Christopher B. Blackwood

Received: 6 April 2021

Accepted: 28 April 2021

Published: 30 April 2021

Publisher's Note: MDPI stays neutral with regard to jurisdictional claims in published maps and institutional affiliations.

Copyright: (c) 2021 by the authors. Licensee MDPI, Basel, Switzerland. This article is an open access article distributed under the terms and conditions of the Creative Commons Attribution (CC BY) license (https:/ / creativecommons.org/licenses/by/ $4.0 /)$.

\begin{abstract}
The response of microbial communities to continual and prolonged water exposure provides useful insight when facing global climate changes that cause increased and uneven precipitation and extreme rainfall events. In this study, we investigated an in situ manipulative experiment with four levels of water exposure (ambient precipitation $+0 \%,+25 \%,+50 \%$, and $+100 \%$ of local annual mean precipitation) in a desert ecosystem of China. After 9 years of water addition, Illumina sequencing was used to analyze taxonomic compositions of the soil bacterial, archaeal, and fungal communities. The results showed significant increases in microbial biomass carbon (MBC) at higher amended precipitation levels, with the highest values reported at $100 \%$ precipitation. Furthermore, an increase in the bacterial species richness was observed along the water addition gradient. In addition, the relative abundance of several bacterial phyla, such as Proteobacteria, significantly increased, whereas that of some drought-tolerant taxa, including Actinobacteria, Firmicutes, and Bacteroidetes, decreased. In addition, the phyla Planctomycetes and Nitrospirae, associated with nitrification, positively responded to increased precipitation. Archaeal diversity significantly reduced under $100 \%$ treatment, with changes in the relative abundance of Thaumarchaeota and Euryarchaeota being the main contributors to shifts in the archaeal community. The fungal community composition was stable in response to water addition. Results from the Mantel test and structural equation models suggested that bacterial and archaeal communities reacted contrastingly to water addition. Bacterial community composition was directly affected by changing soil moisture and temperature, while archaeal community composition was indirectly affected by changing nitrogen availability. These findings highlight the importance of soil moisture and nitrogen in driving microbial responses to long-term precipitation changes in the desert ecosystem.
\end{abstract}

Keywords: global climate change; water addition; Illumina sequencing; desert; microbial community

\section{Introduction}

Anthropogenic emission of greenhouse gases increase the Earth's surface temperature and significantly affects the global hydrological cycle [1,2]. According to global circulation models (GCMs), precipitation and frequency of extreme rainfall events will increase during the 21st century [3]. Such altered precipitation patterns are likely to significantly impact the soil microbial activity and plant productivity in water-limited regions (e.g., arid and semi-arid regions), as water availability is the main limiting factor [4,5]. Deserts, as typical ecosystems in arid regions, cover approximately 19\% of the Earth's terrestrial surface [6]. They support ca. $6 \%$ of the human population and store almost $15 \%$ of the Earth's organic 
carbon $[7,8]$. Considering their relevance to important ecosystem services, it is essential to understand the consequential effect of precipitation changes on desert ecosystems.

As conditions of desert surface soil are extremely harsh (e.g., oligotrophy, water scarcity, large temperature fluctuations, and high ultraviolet radiation [9]), plant and animal life is limited, with soil microbes being the most productive components in the ecosystem [10]. However, desert microbial communities are highly vulnerable to precipitation pattern changes, as substrate availability in desert soil is predominately controlled by soil's water availability. Thus, increasing precipitation induced by global climate change may have profound impacts on the structures of indigenous microbial communities $[5,11]$. Since microbes are dominant drivers of biogeochemical cycling in ecosystems [5,11,12], changes in microbial community composition might ultimately cause changes in ecosystem functions.

Based on previous reports, increased precipitation generally enhances microbial biomass and richness in desert soils $[4,13,14]$. Studies on the response of microbial community composition to precipitation increase have found that bacteria and fungi performed differently. Specifically, bacteria generally responded faster than fungi to water availability changes $[15,16]$. This was attributed to differences in their cell structure and physiological traits $[17,18]$. Fungal hyphae can tolerate low water availability due to their ability to access water from distant micropores with their extensive hyphae [19-21]. However, compared with bacteria and fungi, archaea in desert environments have, so far, received considerably less attention. Similar to soil bacteria and fungi, archaea are major components of belowground diversity and participate in various biogeochemical processes, such as organic carbon degradation [22] and methane production [23]. Recent studies have suggested that archaea are potentially crucial for nitrogen cycling in desert soils $[24,25]$. Additionally, despite decades of research on soil microbial community in desert ecosystems, most studies have only made use of traditional technologies, such as denaturing gradient gel electrophoresis (DGGE) analysis [26] and fatty acid methyl ester (FAME) analysis [17]. More precise methods in this field (i.e., high-throughput sequencing) are limited, particularly in descriptions of the microbial community composition under precipitation changes [20,27]. Compared with traditional technologies, high-throughput sequencing can provide extensive data on microbial community diversity and dynamics. Thus, enabling a more in depth resolution of changes in the microbial community, to deepen our knowledge of desert ecosystems and their response to climate change.

As microbial responses are complex in their direction and magnitude, they tend to be inconsistent over time [28]. For example, one study conducted in the Chihuahuan Desert found that in the first two years, responses of the microbial community due to increased precipitation levels were insignificant, but after three to five years; higher microbial biomass, arbuscular mycorrhizae abundance, and soil enzyme activities were observed [17], suggesting a prolonged response by microbial communities. This is most likely caused by microbial resistance to environmental disturbances [4]. Furthermore, short-term precipitation pulses may induce increased microbial decomposition rates; however, it would be attenuated by long-term environmental adaptation of microbial communities [17]. Since the effects of precipitation increase are evident in the long-term, experiments over longer timescales are needed to examine the effects of such changes on soil microbes in desert ecosystems.

In this context, we experimented with four levels of water addition (ambient precipitation $+0 \%,+25 \%,+50 \%$, and $+100 \%$ of local annual mean precipitation) in a desert in China, to examine the effects of long-term precipitation increases on the soil microbial community. The experiment started in May 2008, and included the determination of various soil physico-chemical parameters to detect changes in environmental variables. We adopted Illumina sequencing of $16 \mathrm{~S}$ rRNA gene amplicons to individually distinguish the taxonomic compositions of bacterial, archaeal, and fungal communities, aiming to answer the following three questions: (1) How do bacterial, archaeal, and fungal communities respond to long-term water addition in a desert ecosystem? (2) What are the specific taxa 
that are responsible for the water addition-induced alterations in these communities? (3) What are the key environmental factors controlling variations of these communities?

\section{Materials and Methods}

\subsection{Study Site}

The study was conducted in a desert ecosystem on the northeast edge of the Ulan Buh Desert $\left(40^{\circ} 24^{\prime} \mathrm{N}, 106^{\circ} 43^{\prime} \mathrm{E}, 1050 \mathrm{~m}\right.$ a. s. 1.). This site is located in Dengkou County, Inner Mongolia, China, and is managed by the Experimental Center of Desert Forestry of the Chinese Academy of Forestry. This area is characterized by an arid continental climate, with a mean annual temperature of $7.8^{\circ} \mathrm{C}$ and mean annual precipitation of $145 \mathrm{~mm}$ (1961-2000); 77.5\% of the annual precipitation occurs between June and September. The mean annual potential evaporation is $2327 \mathrm{~mm}$ [29] and precipitation during the growing season is expected to increase in the future [30]. The vegetation type is temperate desert shrubland with a community cover of $20-30 \%$. The plant community develops on nabkhas (a sand dune that forms around vegetation) and is solely dominated by the widely distributed desert shrub species, Nitraria tangutorum, while the semi-shrub Artemisia ordosica, the perennial grass Psammochloa villosa, the annual grasses Agriophyllum squarrosum and Corispermum mongolicum can also be found. Many N. tangutorum nabkhas are scattered on red clay ground to form a mosaic desert landscape. The soils are classified as sandy soil and gray-brown desert soil (Cambic Arenosols and Luvic Gypsisols in FAO taxonomy).

\subsection{Experimental Design}

In 2008, 16 plots with a diameter of $12 \mathrm{~m}$ were established within the experimental area in a randomized block design. Plots were separated by a buffer zone of more than $5 \mathrm{~m}$ to avoid interactions. Within each plot, one natural nabkha was situated in the center. The height of the nabkhas ranged within 1.18-1.40 m, with base-diameters of $5.75-8.83 \mathrm{~m}$. We selected nabkhas with similar growing conditions and applied four water addition levels: control $(C)=$ ambient precipitation, $\mathrm{W} 25=$ ambient precipitation $+25 \%$ of local annual mean precipitation, $\mathrm{W} 50=$ ambient precipitation $+50 \%$ of local annual mean precipitation, and $\mathrm{W} 100=$ ambient precipitation $+100 \%$ of local annual mean precipitation. The treatments were equally applied on the 15th of each month from May to September, with four replicates per treatment. The water used in the experiments were pumped from a nearby well into a tank and then sprayed onto the plots using an irrigation system installed on the top of each nabkha. Since the two spraying arms of the irrigation system can rotate freely, water could be uniformly sprinkled over the treatment area (Figure S1). To reduce water evaporation, water was applied to the plots in the morning, when the air temperature was relatively low. The groundwater level was below $5 \mathrm{~m}$ and therefore did not affect plant growth. The experimental design was similar to another experiment conducted in Gansu Province, where more detailed information can be found in Song et al., 2012 [31].

Soil samples were collected on 22 September 2016, when soil moisture had stabilized according to the soil moisture records (Figure S2). Since our objective is to estimate average changes of microbial community over the entire nabkha, to minimize effects of inequal root distribution, sampling locations were selected with similar environmental conditions in all nabkha. In addition, in each plot, five representative points (four in the corners and one in the center) of the topsoil (0-20 cm in depth) were randomly collected by a $5 \mathrm{~cm}$ drill. Prior to each sampling event, the drill was cleaned, washed with sterile water, and air dried. Samples from the same plot were pooled to obtain one composite sample, packed in polyethylene bags, immediately stored in a cooler with ice packs, and transferred to the laboratory. The composite samples were sieved through a $2 \mathrm{~mm}$ mesh sieve, and visible roots, residues, and stones were removed. Subsequently, the samples were divided into three parts. One part was stored at $4{ }^{\circ} \mathrm{C}$ for the measurement of soil dissolvable inorganic nitrogen, including nitrate $\left(\mathrm{NO}_{3}{ }^{-}\right)$and ammonium $\left(\mathrm{NH}_{4}{ }^{+}\right)$, soil microbial biomass $\mathrm{C}$ $(\mathrm{MBC})$, and $\mathrm{N}(\mathrm{MBN})$. The second part was air-dried to determine soil $\mathrm{pH}$, total carbon 
(TC), total nitrogen (TN), and total phosphorous (TP), while the third part was stored at $-80{ }^{\circ} \mathrm{C}$ for soil DNA extraction.

\subsection{Measurement of Biotic and Abiotic Factors}

A permanent quadrat of $1 \times 1 \mathrm{~m}$ was established in each plot to conduct plant surveys, recording plant species and species richness. The percentage of plant cover was measured in each quadrat using a $1 \times 1 \mathrm{~m}$ metal pane with 100 equal grids $(10 \times 1.0 \mathrm{~cm})$ by counting the grid junctions whose vertical projections overlapped with the plant species. Plant coverage was visually estimated for species not present at the junctions or present at the junctions but occupying small areas in the quadrat.

The long-term soil temperature and soil moisture dynamics at a depth of $20 \mathrm{~cm}$ were automatically monitored hourly by EM50 data logger systems (Decagon, WA, USA) in four typical plots within each treatment; the values were averaged over the entire month. Soil $\mathrm{pH}$ was determined in $1 \mathrm{~mol} \mathrm{~L}^{-1} \mathrm{KCl}$ extracts. Extractable ammonium $\left(\mathrm{NH}_{4}{ }^{+}\right)$concentrations and extractable nitrate $\left(\mathrm{NO}_{3}{ }^{-}\right)$concentrations were determined by extracting $10 \mathrm{~g}$ of fresh soil samples with $50 \mathrm{~mL} 2 \mathrm{~mol} \mathrm{~L}^{-1} \mathrm{KCl}$. Subsequently, the $\mathrm{KCl}$ extracts were analyzed with a continuous flow analyzer (Futura, Alliance Instruments, Paris, France). Soil organic carbon contents were determined using a sulfuric acid and aqueous potassium dichromate $\left(\mathrm{K}_{2} \mathrm{Cr}_{2} \mathrm{O}_{7}\right)$ mixture with external heating [32]. Soil temperature, soil moisture, $\mathrm{NH}_{4}{ }^{+}$ concentrations, $\mathrm{NO}_{3}{ }^{-}$concentrations, and soil organic carbon were measured in 2016 (year 9 of the experiment). Soil microbial biomass C (MBC) and N (MBN) levels were determined in 2017 (year 10 of the experiment) by using the chloroform fumigationextraction method [33].

\subsection{Soil DNA Extraction and Sequencing}

Total DNA was extracted from $0.5 \mathrm{~g}$ of soil per replicate, using a Power Soil DNA kit (Mo Bio Laboratories, Carlsbad, California, USA) according to the manufacturer's instructions. All samples had a 260/280 ratio between 1.6 and 2.0. Final DNA concentrations were quantified using the Quant-IT Pico Green dsDNA Kit (Invitrogen Molecular Probes Inc., Oregon, USA). The V4 hypervariable region of bacterial $16 \mathrm{~S}$ rRNA gene was amplified with the barcoded primer set consisting of 515F (5'-GTGCCAGCMGCCGCGGTAA-3') and 806R (5'-GGACTACHVGGGTWTCTAAT- $\left.3^{\prime}\right)$. The V4 hypervariable region of archaea $16 \mathrm{~S}$ rRNA gene was amplified using the barcoded primer set of Arch519F (5'-CAGCCGCCGCGGTAA$\left.3^{\prime}\right)$ and Arch915R (5'-GTGCTCCCCCGCCAATTCCT-3'). The ITS1 region of the fungal rRNA gene was amplified by the primers ITS5-1737F $\left(5^{\prime}\right.$-GGAAGTAAAAGTCGTAACAAG G-3') and ITS2-2043R (5'-GCTGCGTTCTTCATCGATGC-3'). Bacterial, archaeal, and fungal amplicons were sequenced on an Illumina HiSeq2500 platform [34] at Novogene Bioinformatics Technology Co. Ltd. (Beijing, China). All Sequencing libraries were generated using the TruSeq ${ }^{\circledR}$ DNA PCR-Free Sample Preparation Kit (Illumina, San Diego, CA, USA), following the manufacturer's recommendations and index codes were added. The library quality was assessed on the Qubit ${ }^{\circledR}$ 2.0 Fluorometer (Life Technologies, Carlsbad, CA, USA) and the Agilent Bioanalyzer 2100 system (Agilent Technologies Inc., Santa Clara, CA, USA). Finally, the library was sequenced on an Illumina HiSeq2500 platform, and $250 \mathrm{bp}$ paired-end reads were generated. Paired-end reads were assigned to samples based on their unique barcodes and truncated by cutting off the barcode and primer sequence. Paired-end reads were merged using FLASH (V1.2.7, http:/ /ccb.jhu.edu/software/FLASH/, accessed on 1 October 2017) and merged sequences were quality filtered according to the QIIME (V1.7.0, http://qiime.org/index.html, accessed on 31 October 2017) [35] with default settings. The tags were compared with the reference database (Gold database, http:/ / drive5.com/uchime/uchime_download.html, accessed on 10 November 2017) using UCHIME algorithm (UCHIME Algorithm, http: / /www.drive5.com/usearch/manual/uchime_algo.html, accessed on 25 October 2017) to detect chimera sequences, and subsequently, the chimera sequences were removed. Sequence analyses were performed by UPARSE (v7.0.1001, http:/ / drive5.com/uparse/, 
accessed on 1 December 2017 [36]). Sequences with $\geq 97 \%$ similarity were assigned to the same OTUs. For each OTU, the most abundant sequence was regarded as its representative sequence, and subsequently, representative sequences were assigned taxonomy information with the Silva database as a reference. Non-bacterial sequences were discarded. The final number of bacterial sequence reads ranged from 57,913 to 74,977 per sample. To correct the bias caused by different sequencing depths, the sequence data were normalized to 57,913 sequences per sample. For archaeal samples, non-archaeal sequences were discarded after the step of assigning representative sequence taxonomy information with the Silva database [37]. Finally, the number of archaeal sequence reads ranged from 24,965 to 53,260 per sample. Archaeal communities were rarefied to 24,965 sequences. For fungi samples, representative sequences were assigned taxonomy information with the UNITE database as a reference. The number of fungal sequence reads ranged from 62,444 to 82,375 per sample; fungal communities were rarefied to 62,444 sequences. In total, 40 bacterial, 7 archaeal, and 6 fungal phyla were detected. Sequence reads generated in this study were archived in the sequence read archive database of the National Center for Biotechnology Information under accession number PRJNA563974.

\subsection{Statistical Analysis}

Microbial alpha- diversity was assessed based on the observed species (species richness), the Shannon-Wiener index $(\mathrm{H})$, and Pielou's evenness (J). Differences in microbial community composition (Bray-Curtis dissimilarity) among the different treatments were assessed by permutational multi-variate ANOVA (PERMANOVA) and visualized using principal coordinate analysis (PCoA). One-way ANOVA was conducted to compare the effects of different water addition treatments. Post hoc analyses were performed using Fisher's least significant difference (LSD) test and the Mantel test was used to test relationships between plant/soil variables and the microbial community compositions. Structural equation modeling (SEM) was performed to specifically test the direct and indirect effects of water addition on the compositions of soil microbial communities (as assessed by PCo1 of the Bray-Curtis dissimilarity matrix). Before conducting SEM analysis, we hypothesized that water addition would impact the bacterial/archaeal/fungi communities, either directly by increasing water availability, or indirectly through changing plant coverage and soil variables (e.g., TC, TN, and $\mathrm{NO}_{3}{ }^{-}$), based on our ANOVA and Mantel test results. The data matrix was fitted to the model using the maximum likelihood estimation method [38]. The overall goodness-of-fit of our model was characterized by a non-significant chi-square test $(p>0.05)$, a low Akaike information criteria (AIC), a low root-mean-square error of approximation (RMSEA $<0.05$ and $p>0.1$ ), and a comparative fit index (CFI) $>0.95$. The Benjamini-Hochberg method (false discovery rate; FDR) was applied to correct the $P$-values after performing multiple comparisons [39].

All statistical analyses and figures described above were completed with R 3.3.1 (www.R-project.org, accessed on 10 December 2020) [40]. The vegan package [41] was used for computing the Bray-Curtis dissimilarity, the Mantel test, and the PCoA. The package pairwise.adonis was used for conducting the PERMANOVA [42]. The lavaan package [43] was employed for SEM, and the ggplot2 package [44] for generating the figures.

\section{Results}

\subsection{Soil and Plant Variables in Different Water Addition Treatments}

As expected, soil moisture increased from 3.2\% (control) to 3.8\% (W50) and 6.8\% (W100) with increased water addition (Table 1), with increment rates of 1, 21.5, and 114.0\%, respectively. However, our study site showed low total carbon and nitrogen values which were significantly enhanced by $100 \%$ water addition compared to the control and other water addition treatments (Table 1$)$. Average increases in total carbon $(0.06 \mathrm{~g}$ TC $/ \mathrm{kg}$ soil) and total nitrogen $(0.04 \mathrm{~g} \mathrm{TN} / \mathrm{kg}$ soil) corresponded to $60.0 \%$ of total soil carbon and $28.6 \%$ of total nitrogen. Although plant coverage did not demonstrate significant changes, 
it increased along the water addition gradient (from $25.0 \%$ in control plots to $33.8 \%$ in W100 plots, $p=0.20)$. In addition, total soil phosphorus, $\mathrm{pH}$, nitrate concentration $\left(\mathrm{NO}_{3}{ }^{-}\right)$, and plant species did not show any significant differences among different treatments. Ammonium concentrations $\left(\mathrm{NH}_{4}{ }^{+}\right)$were below the detection limit in all treatments.

Table 1. Effects of water addition on soil and aboveground plant properties. Values represent mean values and standard deviations $(n=4)$.

\begin{tabular}{ccccc}
\hline & $\mathbf{C}$ & W25 & W50 & W100 \\
\hline September mean soil moisture $(20 \mathrm{~cm}, \%)$ & 3.17 & 3.20 & 3.85 & 6.79 \\
September mean soil temperature $\left(20 \mathrm{~cm},{ }^{\circ} \mathrm{C}\right)$ & 23.58 & 24.28 & 20.09 & $\mathbf{2 2 . 3 6}$ \\
$\mathrm{NO}_{3}^{-}\left(\times 10^{-3} \mathrm{~g} \cdot \mathrm{kg}^{-1}\right)$ & $\mathbf{1 . 5 0} \pm \mathbf{0 . 2 8} \mathbf{a}$ & $\mathbf{1 . 1 9} \pm \mathbf{0 . 2 3} \mathbf{a}$ & $\mathbf{0 . 8 6} \pm \mathbf{0 . 0 6} \mathbf{a}$ & $\mathbf{1 . 4 9} \pm \mathbf{0 . 3 8} \mathbf{a}$ \\
$\mathrm{TC}^{2}\left(\mathrm{~g}^{1} \mathrm{~kg}^{-1}\right)$ & $\mathbf{0 . 1 0} \pm \mathbf{0 . 0 2} \mathbf{b}$ & $\mathbf{0 . 1 0} \pm \mathbf{0 . 0 1} \mathbf{b}$ & $\mathbf{0 . 1 0} \pm \mathbf{0 . 0 1} \mathbf{b}$ & $\mathbf{0 . 1 6} \pm \mathbf{0 . 0 5} \mathbf{a}$ \\
$\mathrm{TN}\left(\mathrm{g} \cdot \mathrm{kg}^{-1}\right)$ & $\mathbf{0 . 1 4} \pm \mathbf{0 . 0 2} \mathbf{b}$ & $\mathbf{0 . 1 5} \pm \mathbf{0 . 0 1} \mathbf{b}$ & $\mathbf{0 . 1 4} \pm \mathbf{0 . 0 1} \mathbf{b}$ & $\mathbf{0 . 1 8} \pm \mathbf{0 . 0 3} \mathbf{a}$ \\
$\mathrm{TP}\left(\times 10^{-4} \mathrm{~g} \cdot \mathrm{kg}^{-1}\right)$ & $1.37 \pm 0.05 \mathrm{a}$ & $1.43 \pm 0.05 \mathrm{a}$ & $1.39 \pm 0.09 \mathrm{a}$ & $1.51 \pm 0.07 \mathrm{a}$ \\
$\mathrm{pH}$ & $7.89 \pm 0.031 \mathrm{a}$ & $7.89 \pm 0.045 \mathrm{a}$ & $7.85 \pm 0.03 \mathrm{a}$ & $7.89 \pm 0.02 \mathrm{a}$ \\
Plant coverage $(\%)$ & $25.0 \pm 7.07 \mathrm{a}$ & $31.25 \pm 4.79 \mathrm{a}$ & $26.25 \pm 11.09 \mathrm{a}$ & $33.75 \pm 9.47 \mathrm{a}$ \\
Plant species & $7.25 \pm 1.50 \mathrm{a}$ & $8.25 \pm 0.96 \mathrm{a}$ & $7.00 \pm 0.82 \mathrm{a}$ & $6.75 \pm 0.96 \mathrm{a}$ \\
\hline
\end{tabular}

\footnotetext{
${ }^{1}$ Values in bold indicate significant responses to water addition, as assessed by one-way ANOVA. Lowercase letters in bold depict significant differences across treatments. ${ }^{2}$ Abbreviations: TC, total carbon; TN, total nitrogen; TP, total phosphorus; $\mathrm{C}=$ ambient precipitation; $\mathrm{W} 25=$ ambient precipitation $+25 \%$ of local annual mean precipitation; W50 $=$ ambient precipitation $+50 \%$ of local annual mean precipitation; $\mathrm{W} 100=$ ambient precipitation $+100 \%$ of local annual mean precipitation.
}

\subsection{Soil Microbial Biomass, Diversity, and Community Composition}

$\mathrm{MBC}$ increased along the water addition gradient and reached maximum values in the W100 plots (from $11.7 \pm 4.1 \%$ in control to $73.7 \pm 6.9 \%$ in W100 plots), being 6.29 times higher than in the control (Figure S3). However, MBN could not be detected because of the low content.

To further dissect the changes in soil bacterial, archaeal, and fungal communities after water addition, we evaluated the alpha diversities in these communities. For bacteria, water addition treatments significantly increased species richness by $17.5 \%$ in W100 plots (Figure 1a). Although the Shannon diversity index and Pielou's evenness index increased compared to the control, these differences were insignificant (Figure 1b,c). For archaea, water addition did not significantly affect species richness (Figure 1d), but significantly decreased the Shannon diversity index by $7.3 \%$ and Pielou's evenness index by $8.4 \%$ in W100 plots (Figure 1e,f). For fungi, water addition had no significant impact on species richness, Shannon diversity index, and Pielou's evenness index compared with the control plots (Figure 1g-i).

Unconstrained principal coordinate analyses (PCoAs) based on the Bray-Curtis distance matrix of OTU relative abundances were performed to investigate patterns of microbial communities (Figure $2 \mathrm{a}-\mathrm{c}$ ). The PCoA plots showed that at the OTU $\mathrm{O}_{0.03}$ level, both bacterial and archaeal communities shifted in composition by water addition treatments whereas fungal communities in W100 plots tended separate from the control, though with overlap. Bacterial axes 1 and 2 explained $29.4 \%$ and $12.5 \%$ of the variance (Figure $2 \mathrm{a}$ ), respectively, while archaeal axes 1 and 2 explained $44.6 \%$ and $33.7 \%$ of the variance (Figure $2 \mathrm{~b}$ ), respectively. Fungal axes 1 and 2 explained $29.9 \%$ and $16.4 \%$ of the variance (Figure 2c), respectively. The permutational multivariate analysis of variance (PerMANOVA), function Adonis (vegan package for R), confirmed that water addition had significant effects on bacterial taxonomic communities $\left(\mathrm{R}^{2}=0.422, p=0.001\right.$, Table S1) and archaeal taxonomic communities $\left(\mathrm{R}^{2}=0.558, p=0.001\right.$, Table $\left.\mathrm{S} 1\right)$, and had weakly statistically significant effects on fungal taxonomic communities $\left(\mathrm{R}^{2}=0.276, p=0.057\right.$, Table S1). 

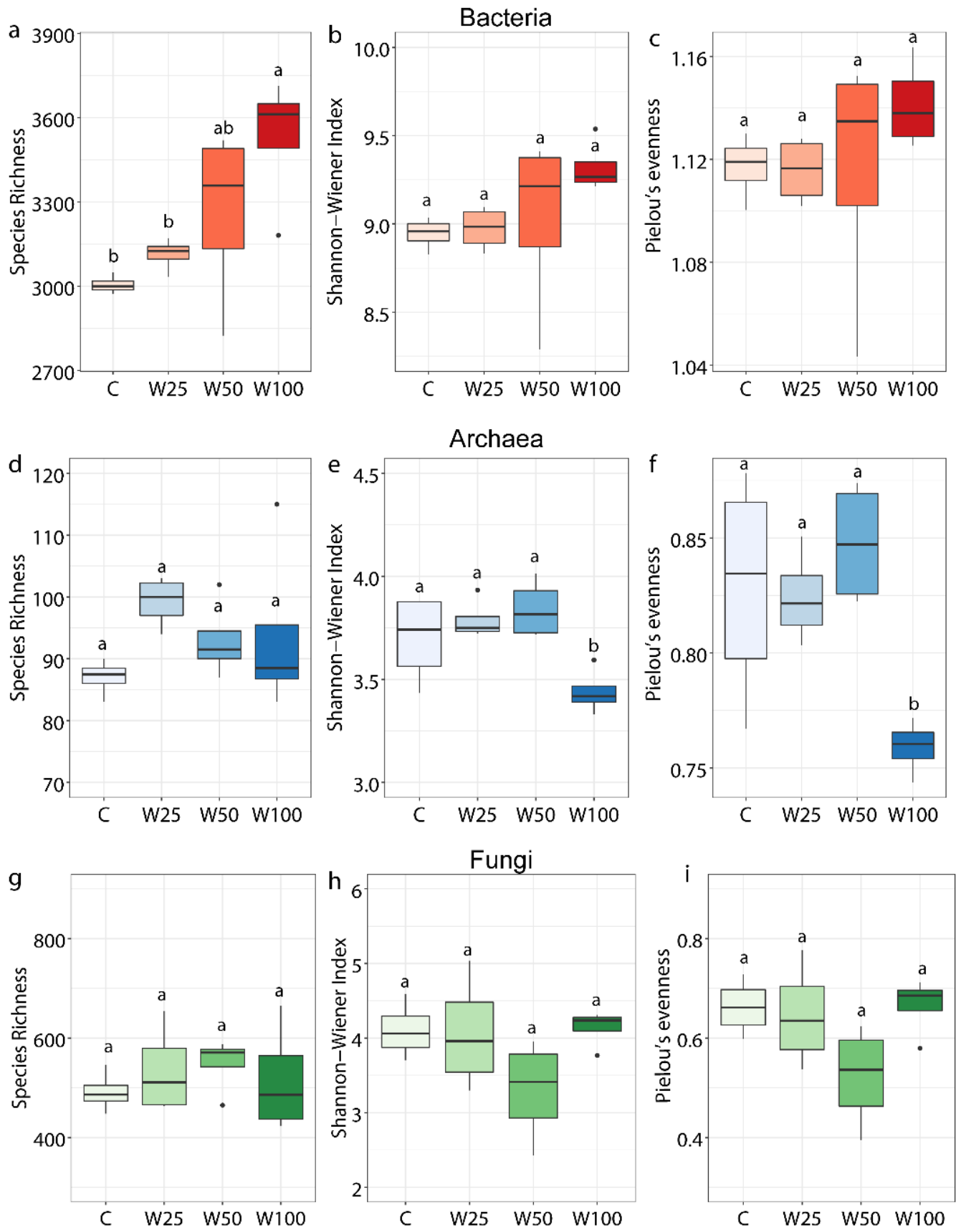

Figure 1. Alpha-diversity of bacterial $(\mathbf{a}-\mathbf{c})$, archaeal $(\mathbf{d}-\mathbf{f})$, and fungal $(\mathbf{g}-\mathbf{i})$ taxonomic communities in different water addition treatments. Boxes represent values from the lower $1 / 4$ quantile to the upper $1 / 4$ quantile. The tops and bottoms of boxes represent the upper $95 \% \mathrm{CI}$ and the lower $95 \% \mathrm{CI}$, respectively. Outliers are drawn as black solid circles above or below boxes. Lowercase letters depict significant differences across treatments. $\mathrm{C}=$ ambient precipitation; $\mathrm{W} 25=$ ambient precipitation $+25 \%$ of local annual mean precipitation; W50 $=$ ambient precipitation $+50 \%$ of local annual mean precipitation; $\mathrm{W} 100=$ ambient precipitation $+100 \%$ of local annual mean precipitation . 

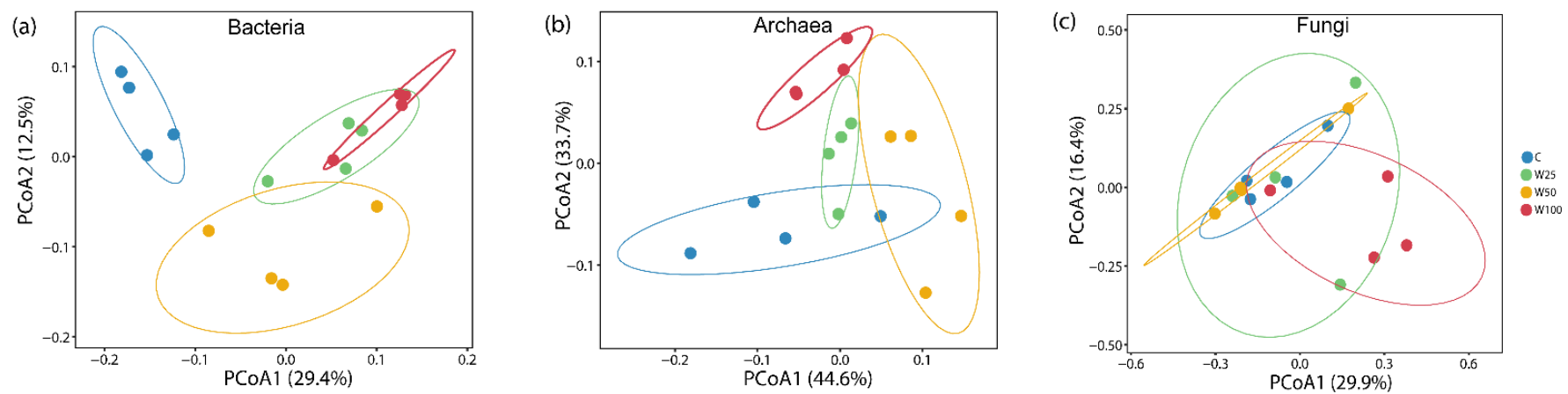

Figure 2. PCoA plots of Bray-Curtis dissimilarities highlighting that bacterial (a), archaeal (b), and fungal (c) communities were significantly different in composition depending on water addition treatments. Circles represent samples from each treatment. $\mathrm{C}=$ ambient precipitation; $\mathrm{W} 25=$ ambient precipitation $+25 \%$ of local annual mean precipitation; $\mathrm{W} 50=$ ambient precipitation $+50 \%$ of local annual mean precipitation; $\mathrm{W} 100=$ ambient precipitation $+100 \%$ of local annual mean precipitation.

\subsection{Responses of Microbial Taxa to Water Addition}

As shown in Figure 3a, bacterial communities were dominated by Actinobacteria $(41.6 \%)$, Proteobacteria (33.3\%), Firmicutes (5.9\%), Acidobacteria (3.4\%), Chloroflexi (4.0\%), Gemmatimonadetes (3.7\%), and Bacteroidetes (2.5\%). The relative abundances of these seven phyla accounted for more than $90 \%$ of the total relative abundance.
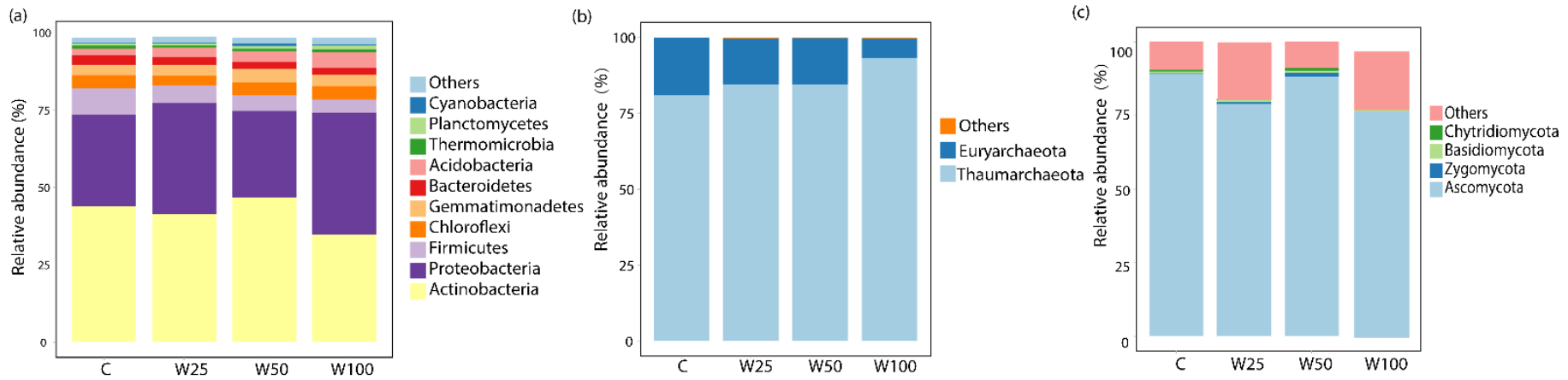

Figure 3. Relative abundances of microbial phyla in bacterial (a), archaeal (b), and fungal (c) communities. $\mathrm{C}=$ ambient precipitation; $\mathrm{W} 25=$ ambient precipitation $+25 \%$ of local annual mean precipitation; $\mathrm{W} 50=$ ambient precipitation $+50 \%$ of local annual mean precipitation; W100 = ambient precipitation $+100 \%$ of local annual mean precipitation.

Water addition significantly increased the relative abundance of Proteobacteria from $29.7 \pm 2.5 \%$ (control) to $39.5 \pm 2.0 \%$ (W100) and that of Acidobacteria from $2 \pm 0.1 \%$ (control) to $5.1 \pm 0.4 \%$ (W100) (Table S2). Intriguingly, we also noticed some functional, but rare taxa with significant increases in abundance (Table S2). For example, the relative abundance of Planctomycetes, which contain a group of anaerobic ammonium-oxidizing (anammox) bacteria, increased significantly by $50.8-170.1 \%$ in water addition plots. The relative abundance of Nitrospirae, which contains a group of nitrite-oxidizing bacteria, increased considerably by $21.6-94.6 \%$ in water addition plots (Table S2). On the contrary, the relative abundances of Actinobacteria significantly decreased from $43.9 \pm 2.1 \%$ (control) to $34.7 \pm 1.9 \%$ (W100). Firmicutes significantly decreased from $8.5 \pm 1.5 \%$ (control) to $4.2 \pm 0.3 \%$ (W100) and Bacteroidetes from $3.2 \pm 0.3 \%$ (control) to $2.1 \pm 0.1 \%$ (W100) (Table S2).

To further investigate the taxonomic compositions of different soil bacterial communities, we compared the water addition response pattern of dominant bacterial taxa at the finer classification levels. At the genus level, a total of 581 genera were identified. However, only two genera significantly decreased in terms of abundance (Figure S4). One was the 
actinobacterial genus Microbacterium ( $p=0.003$ ), which can digest complex organic plant compounds and produce exopolysaccharides $[45,46]$ while the other was from the proteobacterial genus Rubellimicrobium $(p=0.036)$, which is an extremotolerant bacterial taxon that disappears with improved environmental conditions [47]. No genus demonstrated significant increases as a response to water addition.

For archaeal communities, more than $99.7 \%$ of sequences could be classified into two phyla (Figure 3b), Thaumarchaeota (86.6\%) and Euryarchaeota (13.1\%), with the remaining sequences being classified into the newly found phyla, Woesearchaeota $(0.2 \%$, formerly Euryarchaeota DHVEG-6 cluster) and Bathyarchaeota (0.1\%, MCG), as well as other minor phyla. Water addition had remarkable impacts on two dominant archaeal taxa, with Thaumarchaeota abundance increasing from $81 \pm 1.7 \%$ (control) to $93.3 \pm 1.2 \%$ (W100) and Euryarchaeota decreasing from $18.9 \pm 1.7 \%$ (control) to $6.3 \pm 1.0 \%$ (W100) (Table S2). The general patterns of Thaumarchaeota were primarily driven by its major order Candidatus Nitrososphaera, which is associated with ammonia-oxidizing processes and increased from $15.3 \pm 3.3 \%$ in control plots to $21.9 \pm 3.3 \%$ in W100 plots. In contrast, the changes in Euryarchaeota were driven by the abundance of its dominant order Thermoplasmatales, which accounted for $99.9 \%$ in the division of Euryarchaeota (Table S2). The relative abundance of Thermoplasmatales significantly decreased from $18.8 \pm 1.7 \%$ in control plots to $6.3 \pm 3.3 \%$ in W100 plots.

Ascomycota (83.8\%) was the overwhelmingly dominant fungal group, followed by Basidiomycota ( $0.7 \%)$, Zygomycota ( $0.5 \%)$, and Chytridiomycota $(0.3 \%$ ) (Figure 3c)., About $14.6 \%$ of the sequences were unclassified. Furthermore, the ANOVA results showed that water addition had no effects on the relative abundances of any dominant fungal taxa at different class levels (e.g., phylum, order, class, and genus).

\subsection{Relationships between Microbial Communities and Plant/Soil Properties}

To link the microbial community structure with soil and plant properties, Mantel tests were applied to test the correlations between every environmental variable and bacterial, archaeal, and fungal communities (Figure 4). Among all the environmental variables examined, soil moisture at the depth of $20 \mathrm{~cm}$ (Figure 4) showed significant correlations with the soil bacterial community composition. However, no plant properties measured in our study were significantly correlated with soil bacterial community composition. Mantel tests were also applied to examine the potential correlations between individual bacterial phyla and environmental variables. For example, the compositions of Proteobacteria and Acidobacteria were both significantly correlated with soil moisture at the depth of $20 \mathrm{~cm}$ (Table S3), while the composition of Gemmatimonadetes significantly correlated with soil temperature at the depth of $20 \mathrm{~cm}$. In contrast to the bacterial community, the archaeal community composition showed a significant correlation with soil temperature at the depth of $20 \mathrm{~cm}$ (Figure 4) and a marginally significant correlation with soil $\mathrm{NO}_{3}{ }^{-}$. The composition of the most abundant phylum Thaumarchaeota strongly correlated with soil temperature ( $\mathrm{R}=0.309, p=0.017$; Table S3). Another dominant phylum, Euryarchaeota had strong correlations with total nitrogen $(\mathrm{R}=0.606, p=0.001$; Table S3), total carbon $(\mathrm{R}=0.669, p=0.003)$, soil moisture $(\mathrm{R}=0.732, p=0.001)$, and plant coverage $(\mathrm{R}=0.230$, $p=0.019$ ). The fungal community composition only showed a significant correlation with soil moisture at the depth of $20 \mathrm{~cm}$ (Figure 4), while the dominant phylum Ascomycota also correlated with soil moisture at the depth of $20 \mathrm{~cm}(\mathrm{R}=0.246, p=0.051$; Table S3).

We further developed the structure equation model (SEM) to explore the association of the microbial community composition with multiple factors at different water addition levels (Figure 5). Parameters in the model included soil moisture, soil temperature, total nitrogen, total carbon, plant species, and plant coverage. Due to the collinearity of precipitation and soil moisture, precipitation was removed from model parameters. The primary ordination axes (PCoA1) of microbial communities were used to represent the microbial community compositions. The model for bacteria explained $46.5 \%$ of the variation in the bacterial community along the water addition gradient (Figure 5). Soil moisture and plant 
species richness were identified as the significant factors that shape the bacterial community structure. Standardized total effects (including direct and indirect effects) obtained from standardized SEM, suggested that soil moisture contributed most significantly to the variations in the bacterial community structure. The model for archaea explained $36.1 \%$ of the variation in the archaeal community along water addition gradients (Figure 5). The model showed that soil $\mathrm{pH}$ and $\mathrm{NO}_{3}{ }^{-}$had significant direct adverse effects on the archaeal community structure (Figure 5). Similar to results of the Mantel test, soil moisture had no significant direct or indirect effects on the archaeal community composition. In addition, the model for fungi showed that water addition did not directly or indirectly affect the measured parameters of the fungal community composition, which was consistent with the results of the Mantel tests (Figure S5).

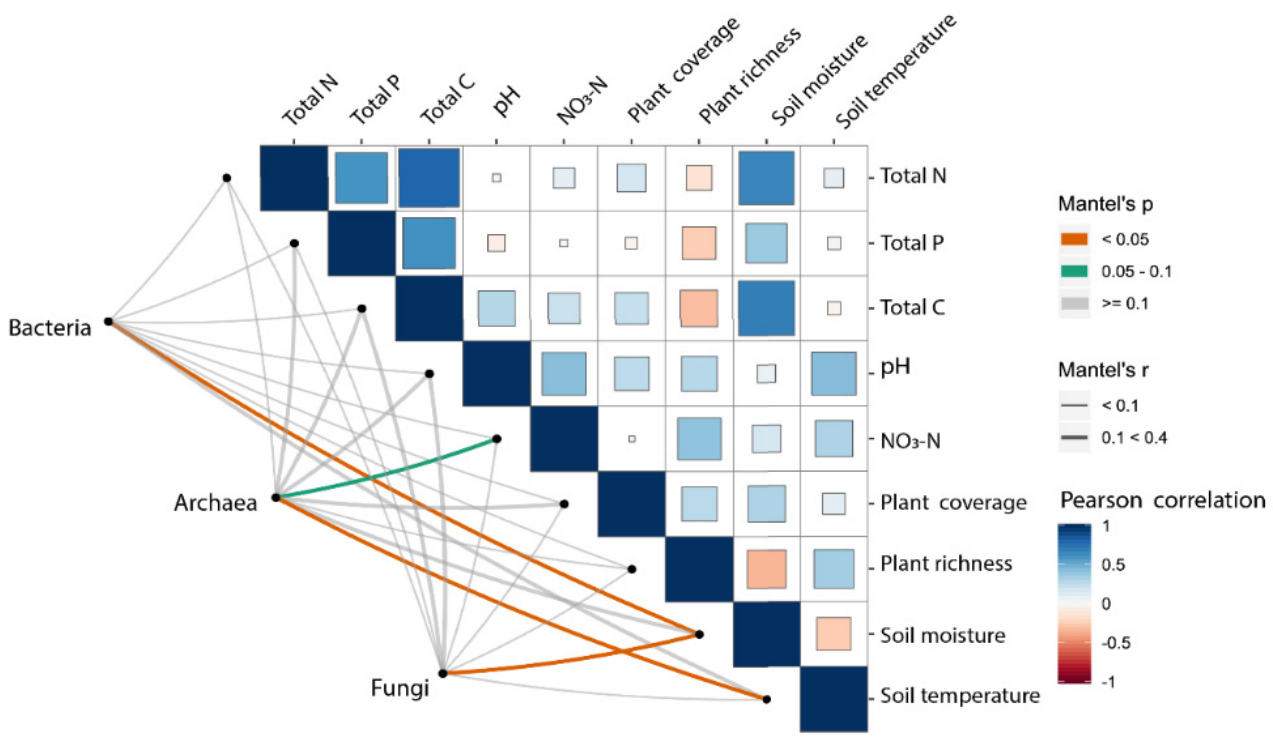

Figure 4. Mantel's correlations between the environmental factors and bacterial, archaeal, and fungal taxonomic communities in different water addition treatments (The widths of lines represent the magnitudes of Mantel's r statistics and the colors indicate the significance of test; the sizes of colored blocks denote the significance of Pearson correlation between two environmental factors, and the absolute values of the Pearson correlation coefficient were labelled along the colored bar on the right).
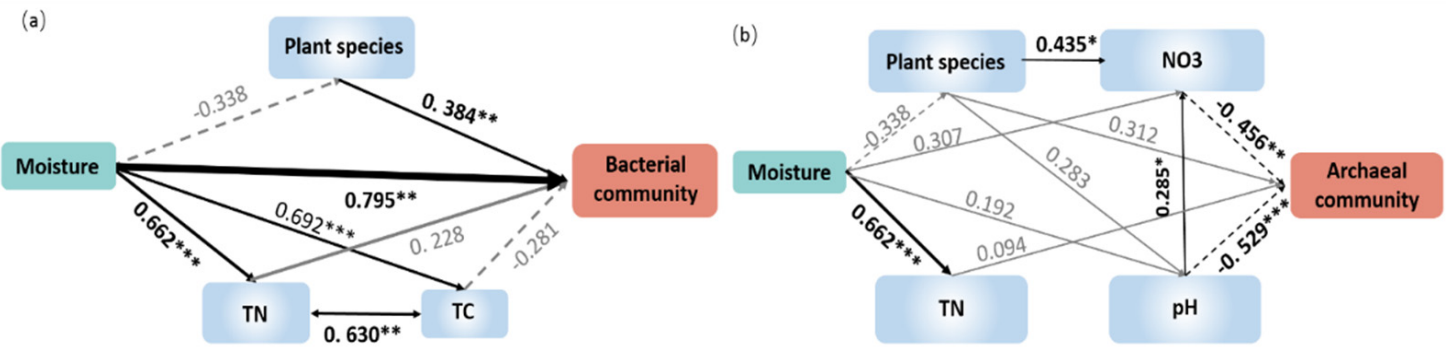

Figure 5. Structural equation modeling showing the relationships between plant/soil properties and the bacterial (a) and archaeal (b) community compositions. Solid arrows indicate positive effects, and the dashed arrow indicates a negative correlation. The standardized path coefficients are adjacent to the arrows and indicate the effect size of the relationship. Arrow widths are proportional to the strength of each relationship. Percentages beside the response variables refer to the proportion of variance explained by the model $\left(\mathrm{R}^{2}\right)$. Results of model fitting: (a) bacteria: $\chi^{2}=0.449, \mathrm{df}=2, p=0.799$; $\mathrm{CFI}=1.000 ; \mathrm{AIC}=36.449 ; \mathrm{RMSEA}=0.000, p=0.806 ;(\mathbf{b})$ archaea: $\chi^{2}=1.833, \mathrm{df}=4, p=0.766 ; \mathrm{CFI}=1.000 ; \mathrm{AIC}=35.834 ;$ $\mathrm{RMSEA}=0.000, p=0.779 . \mathrm{TN}$, soil total nitrogen; TC, soil total carbon; Temperature, soil temperature at the depth of $20 \mathrm{~cm}$; Moisture, soil moisture at the depth of $20 \mathrm{~cm} .{ }^{*} p<0.05,{ }^{* *} p<0.01$, and ${ }^{* * *} p<0.001$. 


\section{Discussion}

Dry climates, scarce surface water, and strong evaporation characterize desert ecosystems, making them fragile and particularly sensitive to climatic changes [17]. In the present study, we used a long-term in situ manipulation model to investigate the effect of increased precipitation on soil bacterial, archaeal, and fungal communities in a desert ecosystem. The nutrient levels in the studied site were relatively low. Some soil variables, such as total nitrogen and total carbon, increased along the water addition gradient. This increase could be because the stimulation of plant growth under water addition increased the production of root exudates and litter input [31,48], which were important sources for soil carbon and nitrogen. In addition, this increase overall explained the increase in microbial biomass with increased precipitation. Furthermore, the compositions of bacterial and archaeal communities were both significantly altered by water addition, indicating that gradual $(25 \%)$ increases in precipitation can substantially alter the soil microbial community composition (see also Bell et al., 2013, Clark et al., 2009, Austin et al., 2004 [13,26,49]). In particular, we observed a generalized increase in bacterial species richness with water addition, which was also recognized in previous desert studies [20,50]. This is most likely because some dormant bacterial taxa are revived when water stress and nutrient stresses are alleviated [51]. However, the Shannon diversity index and Pielou's evenness index in this study experienced minimal change with water addition, most likely due to the uniform contribution of bacterial taxa to the overall abundance. On the contrary, within the archaeal community water addition decreased the Shannon diversity and Pielou's evenness indices. This was attributed to the stimulation of several archaeal taxa by water addition (e.g., Candidatus Nitrososphaera of Thaumarchaeota, Figure 3b and Table S2); whereby the proliferation of these archaeal taxa leads to a decrease in evenness at the community level.

Bacterial communities were dominated by Actinobacteria, Proteobacteria, Firmicutes, Acidobacteria, Chloroflexi, Gemmatimonadetes, and Bacteroidetes, accounting for more than $90 \%$ of the sequences in each of the examined soil samples. The dominant taxa were similar to those observed in other desert systems [6,9,52]. The dominance of Actinobacteria and Firmicutes can be explained by its endospore-forming ability and the high $\mathrm{G}+\mathrm{C}$ content, enabling them to survive in challenging dry conditions [53,54]. Moreover, the phylum of Actinobacteria contains a number of OTUs capable of efficiently hydrolyzing complex substrates, such as starch, cellulose, pectin, and xylan [45], helping them to cope with nutrient-limited conditions. Another dominant phylum, Proteobacteria, had a large proportion of genera that are capable of nitrogen fixation and growing at low carbon or nitrogen concentrations [55]. Hence, in this study the dominant taxonomic groups were specialized in local nutrient-limited and water-limited environments (see also Shade et al., 2012 [56]).

Furthermore, the relative abundance of some specific taxa along the water addition gradient also changed significantly. For example, Proteobacteria and Acidobacteria were more abundant at higher water levels, while Actinobacteria was less abundant in the same plots. Our results are similar to those of previous studies of desert microbial communities $[20,57,58]$, suggesting that water addition facilitates the growth of oligotrophic taxa and suppresses copiotrophic taxa in desert ecosystems. However, previous studies have suggested that increased water availability could stimulate the mineralization of soil organic matter $[49,59]$ and promote the growth of copiotrophic microbes by providing more nutrients. This discrepancy could be attributed to two possible reasons. First, the nutrients released by mineralizing soil organic matter were limited due to low soil organic matter in the desert, therefore not supporting the copiotrophic taxa [20]. This explanation is supported by the low inorganic nitrogen $\left(\mathrm{NO}_{3}{ }^{-}\right.$and $\left.\mathrm{NH}_{4}{ }^{+}\right)$concentrations in all plots. The contents of $\mathrm{NH}_{4}{ }^{+}$were below the detection limit and $\mathrm{NO}_{3}{ }^{-}$was about a twentieth of that in grassland $[60,61]$. As a result, water addition still favored oligotrophic microbes specializing in the use of recalcitrant organics over copiotrophic microbes. Moreover, as shown in previous studies, when the aridity index (AI, the ratio of precipitation to evapotranspiration) is less than 0.2 , the relative abundances of oligotrophic taxa, such as 
Acidobacteria increased with an increasing AI value [20,58], suggesting that oligotrophic taxa are more sensitive to water addition in arid areas. The AI in our study site was 0.06 , far below 0.2 , and therefore, it is reasonable to see that the relative abundance of oligotrophic taxa increased while the copiotrophic taxa decreased with water addition.

Originally, nitrification was thought to include two main steps: the initial oxidation of ammonia to nitrite, and subsequently the oxidation of nitrite to nitrate [62]. Intriguingly, we observed that the relative abundance of the Planctomycetes phylum, which includes members capable of anaerobic ammonium oxidation (anammox) [63], increased significantly with water addition. Furthermore, Nitrospirae, which includes members known to convert nitrite to nitrate in nutrient-low sites [64], increased its abundance with water addition. The increased relative abundances of the above two phyla indicate that water addition facilitated nitrification, which can explain why $\mathrm{NH}_{4}{ }^{+}$concentrations were below the detection limit, while $\mathrm{NO}_{3}{ }^{-}$was stable across all treatments. Another reason for undetectable $\mathrm{NH}_{4}{ }^{+}$is the plant uptake and the enhanced ammonia-volatilization due to a mild alkaline $\mathrm{pH}$ in the desert. Another aspect of $\mathrm{NO}_{3}{ }^{-}$obtained from nitrification, is its consumption by plants for growth, this was supported by the increased plant cover that was observed across all experiments.

Water addition significantly increased the relative abundance of Thaumarchaeota but decreased Euryarchaeota in archaeal communities. Thaumarchaeota have recently received considerable attention as some members are known to perform ammonia oxidation under extremely low ammonium concentrations [65], which is also found in other desert soils worldwide $[27,66,67]$. For example, a recent study conducted in the Tarim Basin by analyzing microbial metagenomic and metatranscriptomic data suggested that Thaumarchaeota are the most important contributors to ammonia oxidation in desert soils [67]. Hence, in our study, the dominance of Thaumarchaeota suggests that the archaeal community in this desert was also dominated by ammonia-oxidizing archaea (AOA). At a closer level, the dominant group Candidatus Nitrososphaera within Thaumarchaeota [68] increased its relative abundance with water addition. This observation was attributed to the increased plant growth, which could provide higher organic substrates for Candidatus Nitrososphaera [69,70]. This matched a previous study that found Candidatus Nitrososphaera performed better in organic-rich habitats [71]. In contrast to the increase in Thaumarchaeota, the relative abundance of Euryarchaeota decreased by water addition (13.1\% in the control to $6.9 \%$ in W100). Interestingly, all the detected euryarchaeal OTUs were classified as Thermoplasmatales at the order level. However, the order of Thermoplasmatales in desert ecosystems remains poorly characterized [72,73], which calls for further investigations.

Our results show that fungal alpha-diversity and community composition were only weakly affected by water addition, this was similar to previous findings in grassland sites, where the relative abundance of various fungal taxa were relatively robust to rewetting [15]. As suggested by previous physiological studies, fungi can produce hyphae at low volumetric soil moisture contents [74], which can help them access water and nutrients from distant micropores under dry conditions. Thus, fungal taxa exhibit a high tolerance to water stresses and changes in desert soils $[75,76]$.

In the present study, we also used Mantel tests to establish linkages between bacterial, archaeal, and fungal communities and environmental variables; we also performed SEM to provide a mechanistic basis for our understanding of how environmental variables mediate alterations in soil microbial community compositions. The bacterial and archaeal communities were both affected by environmental variables; the shifts in the bacterial community composition were primarily caused by soil moisture changes. Similarly, the SEM results suggest that moisture, as well as plant species, directly influenced bacterial communities. Both of the above results indicate that soil moisture was the main factor regulating bacterial communities. This result is in line with a previous study that investigated the distribution of bacteria along a precipitation gradient; it was shown that a change in soil moisture was the main factor that shaped the microbial community composition in a desert ecosystem [77]. 
The Mantel test showed that shifts in archaeal community composition were mainly driven by changes in temperature and $\mathrm{NO}_{3}{ }^{-}$concentrations. Similarly, based on the SEM results, the $\mathrm{NO}_{3}{ }^{-}$concentrations directly affected archaeal communities. Both the above results suggest that the $\mathrm{NO}_{3}{ }^{-}$plays a critical role in shaping archaeal community compositions, although the results from different tests (e.g., Mantel test and SEM) differed slightly. It has also been stated that nitrogen is the second most important factor for desert ecosystems [66]. Our results were similar to those of a study conducted in semi-arid regions in Inner Mongolia, which showed that archaeal community changes were closely correlated to nitrogen contents [66], most likely because major taxonomic groups such as Thaumarchaeota (AOA) are sensitive to soil nitrogen content [24,78]. Although we included all measured environmental variables in the model, we could not find the pathway by which water addition affected archaeal communities. One possible reason is that archaeal community and environmental variables changed nonlinearly along the water addition gradient while another possibility is that some deterministic environmental variables affecting microbial communities in the desert ecosystem were not measured in this study, such as soil electrical conductivity and other soil physico-chemical parameters $[66,79,80]$.

Archaeal and bacterial communities responded in different ways to water addition, probably due to their distinctive niches in desert environments. It has been suggested that soil niches play essential roles in structuring communities [66,81]. Archaea and bacteria occupy different niches, and niches mediating bacterial responses were independent from those mediating archaeal responses $[21,66,77]$. This is consistent with our findings that bacteria were mainly affected by soil moisture, whereas the archaeal community was mainly affected by soil nitrogen contents. Thus, the distinct environmental preferences of bacteria and archaea resulted in different responses of these microbial groups under precipitation changes.

\section{Conclusions}

We provide novel information on long-term water addition effects on soil bacterial, archaeal, and fungal communities in a desert ecosystem. Water addition induced significant changes in bacterial community composition, with increasing abundance of oligotrophic taxa and decreasing abundance of copiotrophic taxa. Water addition also significantly altered archaeal community compositions, increasing the relative abundance of Thaumarchaeota and decreasing that of Euryarchaeota. However, water addition did not alter fungal communities. Our results further suggest that soil moisture is the main factor that drives the shift of bacterial communities, while the soil nitrate content is the main factor driving the archaeal community composition. Given the predominant role of microbes in nutrient cycles, our findings deepen our understanding of the imbalance between nutrient cycles induced by increased precipitation, helping us to assess the systematic ecological responses to climate change.

Supplementary Materials: The following are available online at https://www.mdpi.com/article/10 .3390/microorganisms9050981/s1, Figure S1: Water addition treatments were conducted using an irrigation system, Figure S2: Soil moisture at depth of $10 \mathrm{~cm}$ and $20 \mathrm{~cm}$ of nabkhas under different water addition treatments, Figure S3: Effects of water addition on the soil microbial biomass carbon $(\mathrm{MBC})$, Figure S4: Effects of water addition on the genus of Microbacterium (a) and Rubellimicrobium (b). Means \pm SE are presented $(n=4)$, Figure S5: Structural equation modeling showing the relationships between plant/soil properties and the fungal community compositions, Table S1: PerMANOVA (pairwise comparisons between treatments) to evaluate variations in the bacterial, archaeal and fungal community structure. Significant $p$ values are in bold, Table S2: Results of one-way ANOVA of the effects of water addition $(\mathrm{W})$ on the relative abundances of soil bacterial phyla $(\geq 0.1 \%)$. The mean value and standard error $(n=4)$ of each taxon at each water addition-treatment level $(C, W 25$, W50, and $\mathrm{W100}$ ) are shown in the right columns of the table. $p$ values reflecting statistical significance are shown in boldface. Lowercase letters in the right columns of the table indicate significant differences observed following water addition $(p<0.05)$, Table S3: Correlations between dominant phyla of microbial communities (based on Bray-Curtis distances) and soil and/or plant variables. 
Author Contributions: Conceptualization, Y.G. and B.W.; methodology, Y.G., X.X., and F.B.; data analysis, Y.G. and J.D.; writing-original draft preparation, Y.G.; writing-review and editing, J.D., X.X., F.B., Y.G.D.C., and W.Z., visualization, X.X.; supervision, B.W.; project administration, B.W.; funding acquisition, B.W. All authors have read and agreed to the published version of the manuscript.

Funding: This work was supported by the State Key Research and Development Program of China (2016YFC0500806, 2016YFC0500801), National Natural Science Foundation of China (NSFC 31600394, 42077207) and the remaining funds of Institute of Desertification Studies (IDS2018JY-3 vs. 9).

Institutional Review Board Statement: Not applicable.

Informed Consent Statement: Not applicable.

Data Availability Statement: Sequence reads generated in this study were archived in the sequence read archive database of the National Center for Biotechnology Information under accession number PRJNA563974.

Acknowledgments: The authors would like to thank Novogene Bioinformatics Technology Co. Ltd. (Beijing, China) for help with the data analysis of high throughput sequencing.

Conflicts of Interest: The authors declare no conflict of interest.

\section{References}

1. Vörösmarty, C.J.; Sahagian, D. Anthropogenic Disturbance of the Terrestrial Water Cycle. BioScience 2000, 50, 753-765. [CrossRef]

2. IPCC. Climate Change 2014: The Physical Science Basis: Fifth Assessment Report of the Intergovernmental Panel on Climate Change. 2014. Available online: http:/ / www.ipcc.ch (accessed on 10 December 2020).

3. Meehl, G.A.; Stocker, T.F.; Collins, W.D.; Friedlingstein, P.; Gaye, A.T.; Gregory, J.M.; Kitoh, A.; Knutti, R.; Murphy, J.M.; Noda, A. Global Climate Projections. In Climate Change 2007: The Physical Science Basis. Contribution of Working Group I to the Fourth Assessment Report of the Intergovernmental Panel on Climate Change; Solomon, S., Qin, D., Manning, M., Chen, Z., Marquis, M., Averyt, K.B., Tignor, M., Miller, H.L., Eds.; Cambridge University Press: Cambridge, UK; New York, NY, USA, 2007.

4. Nielsen, U.N.; Ball, B.A. Impacts of altered precipitation regimes on soil communities and biogeochemistry in arid and semi-arid ecosystems. Glob. Chang. Biol. 2015, 21, 1407-1421. [CrossRef] [PubMed]

5. Xu, Z.; Hou, Y.; Zhang, L.; Liu, T.; Zhou, G. Ecosystem responses to warming and watering in typical and desert steppes. Sci. Rep. 2016, 6, 34801. [CrossRef]

6. An, S.; Couteau, C.; Luo, F.; Neveu, J.; DuBow, M.S. Bacterial diversity of surface sand samples from the gobi and Taklamaken deserts. Microb. Ecol. 2013, 66, 850-860. [CrossRef]

7. Lal, R. Carbon sequestration in dryland ecosystems. Environ. Manag. 2004, 33, 528-544. [CrossRef]

8. Stone, R. Have desert researchers discovered a hidden loop in the carbon cycle? Science 2008, 320, 1409-1410. [CrossRef]

9. Ronca, S.; Ramond, J.-B.; Jones, B.; Seely, M.; Cowan, D. Namib Desert dune/interdune transects exhibit habitat-specific edaphic bacterial communities. Front. Microbiol. 2015, 6, 845. [CrossRef]

10. Liu, Y.; Li, X.; Xing, Z.; Zhao, X.; Pan, Y. Responses of soil microbial biomass and community composition to biological soil crusts in the revegetated areas of the Tengger Desert. Appl. Soil Ecol. 2013, 65, 52-59. [CrossRef]

11. Sponseller, R.A. Precipitation pulses and soil $\mathrm{CO}_{2}$ flux in a Sonoran Desert ecosystem. Glob. Chang. Biol. 2007, 13, 426-436. [CrossRef]

12. Falkowski, P.G.; Fenchel, T.; Delong, E.F. The microbial engines that drive earth's biogeochemical cycles. Science 2008, 320, 1034-1039. [CrossRef]

13. Piao, H.C.; Hong, Y.T.; Yuan, Z.Y. Seasonal changes of microbial biomass carbon related to climatic factors in soils from karst areas of southwest China. Biol. Fertil. Soils 2000, 30, 294-297. [CrossRef]

14. Sorensen, P.O.; Germino, M.J.; Feris, K.P. Microbial community responses to 17 years of altered precipitation are seasonally dependent and coupled to co-varying effects of water content on vegetation and soil C. Soil Biol. Biochem. 2013, 64, 155-163. [CrossRef]

15. Barnard, R.L.; Osborne, C.A.; Firestone, M.K. Responses of soil bacterial and fungal communities to extreme desiccation and rewetting. ISME J. 2013, 7, 2229. [CrossRef]

16. Placella, S.A.; Brodie, E.L.; Firestone, M.K. Rainfall-induced carbon dioxide pulses result from sequential resuscitation of phylogenetically clustered microbial groups. Proc. Natl. Acad. Sci. USA 2012, 109, 10931-10936. [CrossRef] [PubMed]

17. Bell, C.W.; Tissue, D.T.; Loik, M.E.; Wallenstein, M.D.; Acosta-Martinez, V.; Erickson, R.A.; Zak, J.C. Soil microbial and nutrient responses to 7 years of seasonally altered precipitation in a Chihuahuan Desert grassland. Glob. Chang. Biol. 2013, 20, 1657-1673. [CrossRef]

18. Cregger, M.A.; Schadt, C.W.; McDowell, N.G.; Pockman, W.T.; Classen, A.T. Response of the soil microbial community to changes in precipitation in a semiarid ecosystem. Appl. Environ. Microbiol. 2012, 78, 8587-8594. [CrossRef] 
19. Boer, W.D.; Folman, L.B.; Summerbell, R.C.; Boddy, L. Living in a fungal world: Impact of fungi on soil bacterial niche development. FEMS Microbiol. Rev. 2005, 29, 795-811. [CrossRef]

20. She, W.; Bai, Y.; Zhang, Y.; Qin, S.; Feng, W.; Sun, Y.; Zheng, J.; Wu, B. Resource availability drives responses of soil microbial communities to short-term precipitation and nitrogen addition in a desert shrubland. Front. Microbiol. 2018, 9, 186. [CrossRef]

21. Sher, Y.; Zaady, E.; Nejidat, A. Spatial and temporal diversity and abundance of ammonia oxidizers in semi-arid and arid soils: Indications for a differential seasonal effect on archaeal and bacterial ammonia oxidizers. FEMS Microbiol. Ecol. 2013, 86, 544-556. [CrossRef]

22. Yu, T.; Wu, W.; Liang, W.; Lever, M.A.; Hinrichs, K.-U.; Wang, F. Growth of sedimentary Bathyarchaeota on lignin as an energy source. Proc. Natl. Acad. Sci. USA 2018, 115, 6022-6027. [CrossRef]

23. Thauer, R.K.; Kaster, A.-K.; Seedorf, H.; Buckel, W.; Hedderich, R. Methanogenic archaea: Ecologically relevant differences in energy conservation. Nat. Rev. Microbiol. 2008, 6, 579. [CrossRef]

24. Marusenko, Y.; Bates, S.T.; Anderson, I.; Johnson, S.L.; Soule, T.; Garcia-Pichel, F. Ammonia-oxidizing archaea and bacteria are structured by geography in biological soil crusts across North American arid lands. Ecol. Process 2013, 2, 9. [CrossRef]

25. Vikram, S.; Guerrero Leandro, D.; Makhalanyane Thulani, P.; Le Phuong, T.; Seely, M.; Cowan Don, A. Metagenomic analysis provides insights into functional capacity in a hyperarid desert soil niche community. Environ. Microbiol. 2015, 18, 1875-1888. [CrossRef]

26. Clark, J.S.; Campbell, J.H.; Grizzle, H.; Acosta-Martìnez, V.; Zak, J.C. Soil microbial community response to drought and precipitation variability in the Chihuahuan desert. Microb. Ecol. 2009, 57, 248-260. [CrossRef] [PubMed]

27. Fierer, N.; Leff, J.W.; Adams, B.J.; Nielsen, U.N.; Bates, S.T.; Lauber, C.L.; Owens, S.; Gilbert, J.A.; Wall, D.H.; Caporaso, J.G. Cross-biome metagenomic analyses of soil microbial communities and their functional attributes. Proc. Natl. Acad. Sci. USA 2012, 109, 21390-21395. [CrossRef] [PubMed]

28. Luo, Y.; Melillo, J.; Niu, S.; Beier, C.; Clark, J.S.; Classen, A.T.; Davidson, E.; Dukes, J.S.; Evans, R.D.; Field, C.B. Coordinated approaches to quantify long-term ecosystem dynamics in response to global change. Glob. Chang. Biol. 2011, 17, 843-854. [CrossRef]

29. Li, Q.; Xu, J.; Li, H.; Wang, S.; Yan, X.; Xin, Z.; Jiang, Z.; Wang, L.; Jia, Z. Effects of aspect on clonal reproduction and biomass allocation of layering modules of Nitraria tangutorum in nebkha dunes. PLoS ONE 2013, 8, e79927. [CrossRef]

30. Ying, S.; Ding, Y.H. A projection of future changes in summer precipitation and monsoon in East Asia. Sci. China Earth Sci. 2010, 53, 284-300.

31. Song, W.; Chen, S.; Wu, B.; Zhu, Y.; Zhou, Y.; Li, Y.; Cao, Y.; Lu, Q.; Lin, G. Vegetation cover and rain timing co-regulate the responses of soil $\mathrm{CO}_{2}$ efflux to rain increase in an arid desert ecosystem. Soil Biol. Biochem. 2012, 49, 114-123. [CrossRef]

32. Nelson, D.W.; Sommers, L.E.; Sparks, D.L.; Page, A.L.; Helmke, P.A.; Loeppert, R.H.; Soltanpour, P.N.; Tabatabai, M.A.; Johnston, C.T.; Sumner, M.E. Total carbon, organic carbon, and organic matter, Part 2 Chemical and Microbiological Properties. In Methods of Soil Analysis; American Society of Agronomy, Inc.: Madison, WI, USA, 1996; Volume 9.

33. Vance, E.D.; Brookes, P.C.; Jenkinson, D.S. An extraction method for measuring soil microbial biomass C. Soil Biol. Biochem. 1987, 19, 703-707. [CrossRef]

34. Caporaso, J.G.; Lauber, C.L.; Walters, W.A.; Berg-Lyons, D.; Huntley, J.; Fierer, N.; Owens, S.M.; Betley, J.; Fraser, L.; Bauer, M.; et al. Ultra-high-throughput microbial community analysis on the Illumina HiSeq and MiSeq platforms. ISME J. $2012,6,1621$. [CrossRef]

35. Caporaso, J.G.; Kuczynski, J.; Stombaugh, J.; Bittinger, K.; Bushman, F.D.; Costello, E.K.; Fierer, N.; Peña, A.G.; Goodrich, J.K.; Gordon, J.I. QIIME allows analysis of high-throughput community sequencing data. Nat. Methods 2010, 7, 335. [CrossRef] [PubMed]

36. Edgar, R.C. UPARSE: Highly accurate OTU sequences from microbial amplicon reads. Nat. Methods 2013, 10, 996. [CrossRef]

37. Quast, C.; Pruesse, E.; Yilmaz, P.; Gerken, J.; Schweer, T.; Yarza, P.; Peplies, J.; Glöckner, F.O. The SILVA ribosomal RNA gene database project: Improved data processing and web-based tools. Nucleic Acids Res. 2013, 41, D590-D596. [CrossRef]

38. Grace, J.B. Structural Equation Modeling and Natural Systems; Cambridge University Press: Cambridge, UK, 2006.

39. Benjamini, Y.; Yekutieli, D. The control of the false discovery rate in multiple testing under dependency. Ann. Stat. 2001, 29, 1165-1188. [CrossRef]

40. R Core Team. R: A Language and Environment for Statistical Computing. Computing 2014, 14, $12-21$.

41. Oksanen, J.; Blanchet, F.G.; Kindt, R.; Legendre, P.; Minchin, P.R.; O'Hara, R.B.; Simpson, G.L.; Solymos, P.; Stevens, M.; Wagner, H. Vegan: Community Ecology Package. R Package Version 2.3-5. 2016. Available online: https://cran.r-project.org/web/ packages/vegan/index.html (accessed on 30 March 2017).

42. Martinez Arbizu, P. pairwiseAdonis: Pairwise Multilevel Comparison Using Adonis. R package version 0.4. 2020. Available online: https: / github.com/pmartinezarbizu/pairwiseAdonis (accessed on 21 October 2020).

43. Rosseel, Y. Lavaan: An R package for structural equation modeling. J. Stat. Softw. 2012, 48, 1-36. [CrossRef]

44. Wickham, H. ggplot2: Elegant Graphics for Data Analysis; Springer: New York, NY, USA, 2009.

45. Favet, J.; Lapanje, A.; Giongo, A.; Kennedy, S.; Aung, Y.-Y.; Cattaneo, A.; Davis-Richardson, A.G.; Brown, C.T.; Kort, R.; Brumsack, H.-J.; et al. Microbial hitchhikers on intercontinental dust: Catching a lift in Chad. ISME J. 2012, 7, 850. [CrossRef] 
46. Lin, L.; Guo, W.; Xing, Y.; Zhang, X.; Li, Z.; Hu, C.; Li, S.; Li, Y.; An, Q. The actinobacterium Microbacterium sp. 16SH accepts pBBR1-based pPROBE vectors, forms biofilms, invades roots, and fixes $\mathrm{N}_{2}$ associated with micropropagated sugarcane plants. Appl. Microbiol. Biotechnol. 2012, 93, 1185-1195. [CrossRef]

47. Köberl, M.; Müller, H.; Ramadan, E.M.; Berg, G. Desert farming benefits from microbial potential in arid soils and promotes diversity and plant health. PLoS ONE 2011, 6, e24452. [CrossRef]

48. Song, W.; Chen, S.; Zhou, Y.; Lin, G. Rainfall amount and timing jointly regulate the responses of soil nitrogen transformation processes to rainfall increase in an arid desert ecosystem. Geoderma 2020, 364, 114197. [CrossRef]

49. Austin, A.T.; Yahdjian, L.; Stark, J.M.; Belnap, J.; Porporato, A.; Norton, U.; Ravetta, D.A.; Schaeffer, S.M. Water pulses and biogeochemical cycles in arid and semiarid ecosystems. Oecologia 2004, 141, 221-235. [CrossRef]

50. Schulze-Makuch, D.; Wagner, D.; Kounaves, S.P.; Mangelsdorf, K.; Devine, K.G.; de Vera, J.-P.; Schmitt-Kopplin, P.; Grossart, H.-P.; Parro, V.; Kaupenjohann, M.; et al. Transitory microbial habitat in the hyperarid Atacama Desert. Proc. Natl. Acad. Sci. USA 2018, 115, 2670-2675. [CrossRef] [PubMed]

51. Lennon, J.T.; Jones, S.E. Microbial seed banks: The ecological and evolutionary implications of dormancy. Nat. Rev. Microbiol. 2011, 9, 119. [CrossRef] [PubMed]

52. Makhalanyane, T.P.; Valverde, A.; Gunnigle, E.; Frossard, A.; Ramond, J.-B.; Cowan, D.A. Microbial ecology of hot desert edaphic systems. FEMS Microbiol. Rev. 2015, 39, 203-221. [CrossRef]

53. Schimel, J.; Balser Teri, C.; Wallenstein, M. Microbial stress-response physiology and its implications for ecosystem function. Ecology 2007, 88, 1386-1394. [CrossRef] [PubMed]

54. Onyenwoke, R.U.; Brill, J.A.; Farahi, K.; Wiegel, J. Sporulation genes in members of the low G+C Gram-type-positive phylogenetic branch (Firmicutes). Arch. Microbiol. 2004, 182, 182-192. [CrossRef]

55. Reith, F.; Brugger, J.; Zammit, C.M.; Gregg, A.L.; Goldfarb, K.C.; Andersen, G.L.; DeSantis, T.Z.; Piceno, Y.M.; Brodie, E.L.; Lu, Z.; et al. Influence of geogenic factors on microbial communities in metallogenic Australian soils. ISME J. 2012, 6, 2107. [CrossRef] [PubMed]

56. Shade, A.; Peter, H.; Allison, S.D.; Baho, D.L.; Berga, M.; Bürgmann, H.; Huber, D.H.; Langenheder, S.; Lennon, J.T.; Martiny, J.B.H. Fundamentals of microbial community resistance and resilience. Front. Microbiol. 2012, 3, 417. [CrossRef] [PubMed]

57. Pointing, S.B.; Belnap, J. Microbial colonization and controls in dryland systems. Nat. Rev. Microbiol. 2012, 10, 551. [CrossRef]

58. Wang, X.; Van Nostrand, J.D.; Deng, Y.; Lü, X.; Wang, C.; Zhou, J.; Han, X. Scale-dependent effects of climate and geographic distance on bacterial diversity patterns across northern China's grasslands. FEMS Microbiol. Ecol. 2015, 91, fiv133. [CrossRef]

59. Grigg, A.M.; Veneklaas, E.J.; Lambers, H. Water relations and mineral nutrition of Triodia grasses on desert dunes and interdunes. Aust. J. Bot. 2008, 56, 408-421. [CrossRef]

60. Zhang, Y.; Dong, S.; Gao, Q.; Liu, S.; Ganjurjav, H.; Wang, X.; Su, X.; Wu, X. Soil bacterial and fungal diversity differently correlated with soil biochemistry in alpine grassland ecosystems in response to environmental changes. Sci. Rep. 2017, 7, 43077. [CrossRef] [PubMed]

61. Xiang, X.; He, D.; He, J.-S.; Myrold, D.D.; Chu, H. Ammonia-oxidizing bacteria rather than archaea respond to short-term urea amendment in an alpine grassland. Soil Biol. Biochem. 2017, 107, 218-225. [CrossRef]

62. Winogradsky, S. Recherches sur les organisms de la nitrification. Ann. Inst. Pasteur 1890, 4, 213-231, 257-275, 760-771.

63. Strous, M.; Fuerst, J.A.; Kramer, E.H.M.; Logemann, S.; Muyzer, G.; van de Pas-Schoonen, K.T.; Webb, R.; Kuenen, J.G.; Jetten, M.S.M. Missing lithotroph identified as new planctomycete. Nature 1999, 400, 446. [CrossRef]

64. Andreas, S.; Dirk, D.B.; Armin, G.; Rudolf, A. Microenvironments and distribution of nitrifying bacteria in a membrane-bound biofilm. Environ. Microbiol. 2000, 2, 680-686.

65. Marusenko, Y.; Garcia-Pichel, F.; Hall, S.J. Ammonia-oxidizing archaea respond positively to inorganic nitrogen addition in desert soils. FEMS Microbiol. Ecol. 2015, 91, 1-11. [CrossRef]

66. Huang, M.; Chai, L.; Jiang, D.; Zhang, M.; Zhao, Y.; Huang, Y. Increasing aridity affects soil archaeal communities by mediating soil niches in semi-arid regions. Sci. Total Environ. 2019, 647, 699-707. [CrossRef] [PubMed]

67. Ren, M.; Zhang, Z.; Wang, X.; Zhou, Z.; Chen, D.; Zeng, H.; Zhao, S.; Chen, L.; Hu, Y.; Zhang, C.; et al. Diversity and contributions to nitrogen cycling and carbon fixation of soil salinity shaped microbial communities in tarim basin. Front. Microbiol. $2018,9,431$. [CrossRef]

68. Breidenbach, B.; Blaser Martin, B.; Klose, M.; Conrad, R. Crop rotation of flooded rice with upland maize impacts the resident and active methanogenic microbial community. Environ. Microbiol. 2015, 18, 2868-2885. [CrossRef]

69. Ye, F.; Wu, S.; Jiang, Y.; Op den Camp, H.J.M.; Li, Z.; Zhu, G.; Zheng, J.; Wang, Y. Shifts of archaeal community structure in soil along an elevation gradient in a reservoir water level fluctuation zone. J. Soils Sediments 2016, 16, 2728-2739. [CrossRef]

70. De Vries, F.T.; Shade, A. Controls on soil microbial community stability under climate change. Front. Microbiol. $2013,4,265$. [CrossRef]

71. Bouali, M.; Zrafi-Nouira, I.; Bakhrouf, A.; Le Paslier, D.; Chaussonnerie, S.; Ammar, E.; Sghir, A. The structure and spatio-temporal distribution of the Archaea in a horizontal subsurface flow constructed wetland. Sci. Total Environ. 2012, 435-436, 465-471. [CrossRef]

72. Finstad, K.M.; Probst, A.J.; Thomas, B.C.; Andersen, G.L.; Demergasso, C.; Echeverría, A.; Amundson, R.G.; Banfield, J.F. Microbial community structure and the persistence of cyanobacterial populations in salt crusts of the hyperarid atacama desert from genome-resolved metagenomics. Front. Microbiol. 2017, 8, 1435. [CrossRef] 
73. Liu, P.; Klose, M.; Conrad, R. Temperature effects on structure and function of the methanogenic microbial communities in two paddy soils and one desert soil. Soil Biol. Biochem. 2018, 124, 236-244. [CrossRef]

74. Treseder, K.K.; Schimel, J.P.; Garcia, M.O.; Whiteside, M.D. Slow turnover and production of fungal hyphae during a Californian dry season. Soil Biol. Biochem. 2010, 42, 1657-1660. [CrossRef]

75. Zhang, X.; Wei, H.; Chen, Q.; Han, X. The counteractive effects of nitrogen addition and watering on soil bacterial communities in a steppe ecosystem. Soil Biol. Biochem. 2014, 72, 26-34. [CrossRef]

76. Gordon, H.; Haygarth, P.M.; Bardgett, R.D. Drying and rewetting effects on soil microbial community composition and nutrient leaching. Soil Biol. Biochem. 2008, 40, 302-311. [CrossRef]

77. Angel, R.; Soares, M.I.M.; Ungar, E.D.; Gillor, O. Biogeography of soil archaea and bacteria along a steep precipitation gradient. ISME J. 2009, 4, 553. [CrossRef] [PubMed]

78. Kuypers, M.M.M.; Marchant, H.K.; Kartal, B. The microbial nitrogen-cycling network. Nat. Rev. Microbiol. 2018, 16, 263. [CrossRef]

79. Frossard, A.; Ramond, J.-B.; Seely, M.; Cowan, D.A. Water regime history drives responses of soil Namib Desert microbial communities to wetting events. Sci. Rep. 2015, 5, 12263. [CrossRef] [PubMed]

80. Ma, X.; Zhao, C.; Gao, Y.; Liu, B.; Wang, T.; Yuan, T.; Hale, L.; Van Nostrand, J.D.; Wan, S.; Zhou, J. Divergent taxonomic and functional responses of microbial communities to field simulation of aeolian soil erosion and deposition. Mol. Ecol. 2017, 26, 4186-4419. [CrossRef]

81. Bates, S.T.; Berg-Lyons, D.; Caporaso, J.G.; Walters, W.A.; Knight, R.; Fierer, N. Examining the global distribution of dominant archaeal populations in soil. ISME J. 2011, 5, 908-917. [CrossRef] [PubMed] 